\title{
Gender differences in santri's reading attitude and motivation
}

\author{
1Banatul Murtafi'ah*, 2Nur Hidayanto Pancoro Setyo Putro \\ ${ }^{1}$ Universitas Islam Indonesia, Indonesia \\ 2Universitas Negeri Yogyakarta, Indonesia \\ *Corresponding Author \\ Email: banatul.murtafi'ah@uii.ac.id
}

\begin{abstract}
A considerable amount of studies has explored gender differences in reading attitude and motivation among students in both elementary and secondary school levels. However, none of them is concerned with English reading attitude and motivation among santri or students living at Islamic boarding school in which gender segregation is applied. This study attempts to investigate santri's reading attitude and reading motivation based on their gender. Three hundred and nineteen students at pesantren-based senior high schools in Yogyakarta Special Region province participated in the study by completing both reading attitude questionnaires and motivational reading questionnaire (MRQ). The results showed that there were significant differences among female and male santris in terms of reading attitude and motivation. The independent sample t-test revealed that female students reported statistically significant higher attitude in both academic and recreational reading than male students. Similarly, female students also reported higher reading motivation in three dimensions of $M R Q$, i.e. reading involvement, importance of reading, and competition in reading than male student. Likewise, regression analysis showed that gender could predict santri's reading attitude and motivation. This study, therefore, confirmed a consistent finding from the previous studies revealing that female students had higher reading attitude and motivation than male students.
\end{abstract}

Keywords: gender differences; santri; reading attitude; reading motivation

Received: Revised: Accepted: Published:

10 October 201915 July $2020 \quad 28$ August $2020 \quad 31$ August 2020

\section{INTRODUCTION}

Reading is one of the prominent skills in the students' learning development especially for English learning since it is useful for second language acquisition (Richards \& Renandya, 2002; Krashen, 2004; Harmer, 2007). Thus, itbecomes the primary source of second language input that enriches learners' knowledge of the language in terms of grammar, discourse structure, and vocabulary (Nation, 2009; Salikin et al., 2017). In Indonesian education context, reading also plays an important role as it becomes the main skill tested in national final examination other than listening. Approximately $70 \%$ of the final examination questions for English subject in senior high school level are reading comprehension questions (BSNP, 2017). In other words, 
Murtafi'ah, B., \& Putro, N.H.P.S. (2020). Gender differences in santri's reading attitude and motivation. EduLite: Journal of English Education, Literature, and Culture, 5 (2), 251-262. DOI: http://dx.doi.org/10.30659/e.5.2.251-262

students' reading comprehension could presumably reflect the final examination achievement. Since final examination is so far the main measurement for the students' achievement in English subject, therefore, research related to reading achievement is needed to conduct.

Recent studies, furthermore, have demonstrated that affective factors of the students such as reading motivation and reading attitude play significant roles to their reading achievement (Wang \& Guhtrie, 2004; Unrau \& Schlackman, 2006; McKenna et al., 2012; Phuong \& Vo, 2019). Another study (i.e. Ilahiyah, et al., 2019) also has investigated the gender difference on reading motivation and writing achievement. However, there has been no detailed investigation of reading attitude and reading motivation among santri or students living in Islamic boarding schools. There is an urgent need to address their reading attitude and reading motivation as the number of santri in Yogyakarta Special Region province is one ninth of general senior high school students (http://bappeda.jogjaprov.go.id/dataku/si/). The fact that gender segregation is implemented in the pesantren also another interesting reason for conducting this study.

Therefore, the main focus of investigation in this present study is on the santri's reading attitude and reading motivation. Specifically, this study sets out to compare the reading attitude and reading motivation dimensions among male and female santri in Yogyakarta Special Region province.

\section{Reading attitude}

Previous studies mostly defined reading attitude as feelings towards reading ranging from positive to negative state; predispositions or tendencies in reading (Petscher, 2010; Conradi et al., 2013; McKenna, et al., 2012); and emotional perceptions related to reading (Grabe, 2009). Therefore, throughout this paper, reading attitude is defined as feelings, predispositions, tendencies, and perceptions related to reading ranging from positive to negative.

Though there were several different measurements of reading attitude from several studies (e.g., Tullock-Rhody \& Alexander, 1980; Smith, 1990; Logan \& Johnston, 2009) this present study adapted the recent tool from McKenna et al., (2012). There were four dimensions of reading attitude in this recent questionnaire, i.e., attitude in academic digital (AD), academic print (AP), recreational digital (RD), and recreational print (RP) settings. This present study, however, included only reading attitude in (1) academic print and (2) recreational print settings only due to the limitation use of internet and gadget from santri in pesantren.

\section{Reading motivation}

Several definitions of reading motivation have been proposed in previous studies. For example, reading motivation is defined as student's personal goals, values, and beliefs with regard to reading (Guthrie \& Wigfield, 2000). Another definition is proposed by Wang and Guthrie (2004) defining reading motivation as student's intrinsic and extrinsic reasons for reading. While these definitions have been suggested, this paper used the definition suggested by 
Wang and Guthrie (2004) who define reading motivation as students' intrinsic and extrinsic causes for reading activities and achievement.

In measuring the students' reading motivation, the present study adapted the most widely used instrument, i.e. Motivation for Reading Questionnaire (MRQ) from Wigfield and Guthrie (1997). Several studies that have adapted this instrument include Baker and Wigfield (1999); Mori (2002); Wang and Guthrie (2004); Unrau and Schlackman (2006). MRQ consists of 11 dimensions including (1) reading efficacy; (2) reading challenge; (3) work avoidance; (4) reading curiosity; (5) reading involvement; (6) importance of reading; (7) competition in reading; (8) reading recognition; (9) reading for grades; (10) social reasons for reading; and (11) reading compliances.

\section{Gender differences in reading attitude and reading motivation}

A considerable number of findings from previous studies have consistently demonstrated that female students have higher reading attitude (e.g. Smith, 1990; McKenna et al., 1995; 2012; Kush \& Watkins, 1996; Ghaith, 2003; Swalander \& Taube, 2007; Logan \& Johnston, 2009; Martinez, Aricak, \& Jewell, 2008; McQuillan, 2013; Bussert-Web \& Zhang, 2016) than male students. Specifically, some studies (e.g. McKenna et al., 1995; 2012) have also found that female students have statistically significant higher reading attitude in academic and recreational print setting.

Likewise, in terms of reading motivation, a consistent finding from some studies (e.g. Wigfield \& Guthrie, 1997; Baker \& Wigfield, 1999; Unrau \& Schlackman, 2006; Kelley \& Decker, 2009; MRQ Marinak \& Gambrell, 2010; McGeown, Goodwin, Henderson, \& Wright, 2011) have reported that female students were found to have higher motivation in reading than male students. However, none of the participants in all these studies were santri or students living in Islamic boarding school.

\section{Santri}

Santri is a term used by Indonesian people which refers to students who live and study in pesantren or Islamic boarding school (Hidayat, 2011; Fauzi, 2012). Pesantren, the place and environment in which santri live and devote time to study, is an educational institution of religious teaching comprising five components including Kiai/Ustadz, santri, mosque, kitab kuning or classical Islamic books written in Arabic, and pondok or dormitory where all santri must stay to learn the Holy Qur'an and other religious scriptures (Dhofier, 2011).

There were four types of pesantren, i.e. type A, B, C, and D according to Muhaimin (2006). While Dhofier (2011) classifies two types of pesantren, namely traditional pesantren and modern pesantren. Type A pesantren has similar characteristics with classical pesantren in which attempt to maintain traditional teaching of Islamic scriptures without embedding secular subjects. Type-B pesantren, in contrast, combines both traditional Islamic scriptures teaching and secular subjects teaching. The secular subjects are taught in formal schools under the authority of pesantren called madrasah. Type-C 
Murtafi'ah, B., \& Putro, N.H.P.S. (2020). Gender differences in santri's reading attitude and motivation. EduLite: Journal of English Education, Literature, and Culture, 5 (2), 251-262. DOI: http://dx.doi.org/10.30659/e.5.2.251-262

pesantren is somewhat similar to Type B. The difference lies only in the supervision for the madrasah in which secular subjects are taught. Type-B pesantren is under the supervision of Ministry of Religious Affair (MORA) and type-C pesantren has both madrasah under MORA and public school under Ministry of Education and Culture (MOEC). Type-D pesantren comprises only dormitory or pondok for the santri. There is no formal school or madrasah in this type of pesantren. Therefore, their santri may attend the formal schools surrounding their pesantren. All the students living in these types of pesantren are called santri. However, the participants were only limited to those living and studying in type-B pesantren.

\section{METHOD}

\section{Participants}

Participants were recruited from santri in grade 10 and grade 11 of four different private Madrasah Aliyah (MA) in four different type-B pesantren in Yogyakarta Special Region province $(\mathrm{N}=319$; males $=133$; females $=186)$. Participants from this type of pesantren were chosen since they learn English as a secular subject in madrasah (school) and Islamic traditional scriptures in pondok (dormitory). Students from other types of pesantren, might only learn Islamic traditional scriptures without learning secular subject or vice versa.

\section{Research Instruments}

The main instrument used in this study was questionnaire. There were two types of questionnaire used in the present study, i.e. the adapted version of reading attitude questionnaire from McKenna (2012) and motivation for reading questionnaire (MRQ) from Wigfield and Guthrie (1997). The early set of reading attitude questionnaire comprised 15 items clustered into two dimensions, i.e., academic reading and recreational reading attitude. However, after being examined using exploratory factor analysis (EFA) and confirmatory factor analysis (CFA), there were only eight items remained from two factors.

Furthermore, the initial set of motivational reading questionnaire (MRQ) comprised 45 items grouped into 11 dimensions, i.e. (1) reading efficacy; (2) reading challenge; (3) work avoidance; (4) reading curiosity; (5) reading involvement; (6) importance of reading; (7) competition in reading; (8) reading recognition; (9) reading for grades; (10) social reasons for reading; and (11) reading compliances. Based on the factor analyses results, only 21 items retained from seven dimensions. These seven dimensions were those used in the analysis: (1) reading challenge; (2) reading involvement; (3) importance of reading; (4) reading efficacy; (5) compliances; (6) competition in reading; and (7) social reasons for reading.

\section{Statistical analysis}

The main analyses used in this study were independent sample $t$-test and regression analysis. The independent sample $t$-test was used to compare the means between two groups on the same continuous variable. In this present study, the independent sample $t$-test was conducted to test the mean score difference of the reading attitude and reading motivation dimensions among 
the santri from grade $\mathrm{X}$ to grade XI based on their gender. Meanwhile, regression analysis was conducted to examine whether gender predicted the reading attitude and reading motivation dimensions. All the analyses were conducted by using SPSS 23 .

\section{RESULTS AND DISCUSSION}

This present study set out to investigate the difference between reading attitude and reading motivation among male and female santri. This section, therefore, discusses the results of the independent sample $t$-test to see the difference across gender and also the results of regression analysis that shows whether gender could predict reading attitude and reading motivation factors.

\section{Independent sample $t$-test Reading attitude}

The first variable measured by using the independent $t$-test was reading attitude. The two reading attitude dimensions were included in the analysis to see whether they were differed by gender. Table 1 displays the result of the analysis. It was found that there were statistically significant differences on academic reading and recreational reading based on gender.

Table 1. Independent Sample $t$-test Result of Reading Attitude by Gender

\begin{tabular}{lcccc} 
& $\begin{array}{c}\text { Male } \\
\boldsymbol{M} \text { (SD) }\end{array}$ & $\begin{array}{c}\text { Female } \\
\boldsymbol{M} \text { (SD) }\end{array}$ & $\begin{array}{c}\boldsymbol{t} \text { - } \\
\text { value }\end{array}$ & $\begin{array}{c}\boldsymbol{p} \text { - } \\
\text { value }\end{array}$ \\
\hline Academic & -.21 & .15 & -2.88 & .004 \\
Reading & $(1.18)$ & $(1.05)$ & & \\
Recreational & -.24 & .17 & -3.27 & .001 \\
Reading & $(1.08)$ & $(1.13)$ & & \\
\hline
\end{tabular}

As can be seen from the table above, female students $(M=.15, S D=1.05)$ reported higher "academic reading" attitude than male students $(M=-.21, S D$ $=1.18 ; t[312]=-2.88, p=.004)$. Likewise, female students $(M=.17, S D=1.13)$ also reported statistically significant higher "recreational reading" attitude compared to male students $(M=-.24, S D=1.08 ; t[311]=-3.27, p=.001)$. Therefore, from the independent sample $t$-test results, it appears female students had statistically significant higher reading attitude than male students.

\section{Reading motivation}

The next variable measured by using $t$-test was reading motivation. An independent sample $t$-test was performed to test whether there is a mean difference among reading motivation factors by gender. Table 2 presents the result of the analysis. From the analysis, it was found that three out of seven factors in reading motivation had significant differences in terms of gender and grade.

As can be seen in Table 2 , female students $(M=.17, S D=1.08)$ showed higher "reading involvement" than male students $(M=-.24, S D=1.10 ; t[317]=$ 
Murtafi'ah, B., \& Putro, N.H.P.S. (2020). Gender differences in santri's reading attitude and motivation. EduLite: Journal of English Education, Literature, and Culture, 5 (2), 251-262. DOI: http://dx.doi.org/10.30659/e.5.2.251-262

-3.30, $p=.001)$. Similarly, female students $(M=.13, S D=1.10)$ also showed higher motivation in terms of "importance of reading" than male students $(M=$ $-.19, S D=1.13 ; t[315]=-2.57, p=.011)$. Similarly, female students $(M=.14$, $S D=1.10)$ also showed higher "competition in reading" than male student $(M$ $=-.20, S D=1.18 ; t[317]=-2.67, p=.008)$. Therefore, from the $t$-test results, it appears female students also had statistically significant higher reading motivation than male students. However, no significant differences on other dimensions (i.e. reading challenge, reading efficacy, compliances, and social reasons for reading by gender) were found from the $t$-test result.

Table 2. Independent Sample $t$-test Result of Reading Motivation by Gender

\begin{tabular}{|c|c|c|c|c|}
\hline & $\begin{array}{l}\text { Male } \\
M \text { (SD) }\end{array}$ & $\begin{array}{r}\text { Female } \\
M \text { (SD) }\end{array}$ & $\begin{array}{c}t- \\
\text { value }\end{array}$ & $\begin{array}{c}p- \\
\text { value }\end{array}$ \\
\hline $\begin{array}{l}\text { Reading } \\
\text { Involvement }\end{array}$ & $\begin{array}{c}-.24 \\
(1.10)\end{array}$ & $\begin{array}{c}.17 \\
(1.08)\end{array}$ & -3.30 & .001 \\
\hline $\begin{array}{l}\text { Importance } \\
\text { of Reading }\end{array}$ & $\begin{array}{c}-.19 \\
(1.13)\end{array}$ & $\begin{array}{c}.13 \\
(1.10)\end{array}$ & -2.57 & .011 \\
\hline $\begin{array}{l}\text { Competition } \\
\text { in Reading }\end{array}$ & $\begin{array}{c}-.20 \\
(1.18)\end{array}$ & $\begin{array}{c}0.14 \\
(1.10)\end{array}$ & -2.67 & .008 \\
\hline
\end{tabular}

\section{Regression analysis}

After investigating the mean score differences of the variables using $t$-test, the next analysis was regression analysis which investigated whether gender based on the result of $t$-test could predict other variables such as reading attitude and reading motivation dimensions. Based on the results of the independent sample $t$-test, only variables which show significant relationships to the reading attitude dimensions and reading motivation dimensions were selected as independent variables. In this case, gender showed some differences on "academic reading". Therefore, gender was used as independent variable for "academic reading". Two dimensions of reading attitude and three dimensions of reading motivation were employed as dependent variables for the regression models.

\section{Reading attitude}

Based on the independent sample t-test, "academic reading" differed by gender. Therefore, in the regression model, gender was used as an independent variable for "academic reading". It can be seen in Table 3 that "academic reading" was statistically significantly predicted by students' gender $(\beta=.16, p<.05)$. The predictor, i.e. gender, explained $2.6 \%$ of the variability in "academic reading".

Similarly, gender was also used to explain students' "recreational reading". In this model, the variable - gender $(\beta=.18, p<.05)-$ was found to be a significant predictor for students' recreational reading attitude. It explained $3.3 \%$ of the variance in "recreational reading". Table 3 presents the summary of the regression analyses for reading attitude dimensions. 
Table 3. Summary of Regression Analysis for Reading Attitude Dimensions

\begin{tabular}{|lllrrr}
\hline No & $\begin{array}{l}\text { Dependent } \\
\text { Variables }\end{array}$ & Predictor & $\begin{array}{c}\mathbf{R} \\
\text { Square }\end{array}$ & t & Sig \\
\hline 1. & $\begin{array}{l}\text { Academic } \\
\text { reading }\end{array}$ & Gender & .026 & 2.879 & .004 \\
2. & $\begin{array}{l}\text { Recreational } \\
\text { reading }\end{array}$ & Gender & .033 & 3.276 & .001 \\
\hline
\end{tabular}

\section{Reading motivation}

The results from independent sample $t$-test showed that among seven dimensions, only three dimensions (i.e. reading involvement, importance of reading, and competition in reading) in which significant differences between female and male students were found. Therefore, these three dimensions were used in the regression analysis as the dependent variables.

Based on the independent sample t-test, "reading involvement" differed by gender. Therefore, in the regression model, gender was used as an independent variable for "reading involvement". As shown in Table 4 that "reading involvement" was statistically significantly predicted by students' gender $(\beta=.18, p<.05)$. The predictor, i.e. gender, explained $3.3 \%$ of the variability in "reading involvement".

In the same vein, gender was also used to explain students' "importance of reading". In this model, gender $(\beta=.14, p<.05)$ was found to be a significant predictor for students' motivation in terms of importance of reading. It explained $2.1 \%$ of the variance in "importance of reading".

Finally, in terms of "competition in reading", gender $(\beta=.14, p<.05)$ was also found to be a significant predictor for students' "competition in reading". It explained $2.2 \%$ of the variability in "competition in reading". Table 4 presents the summary of the regression analyses for reading motivation dimensions.

Table 4. Summary of Regression Analysis for Reading Motivation Dimensions

\begin{tabular}{|lllrrr}
\hline No & $\begin{array}{l}\text { Dependent } \\
\text { Variables }\end{array}$ & Predictor & $\begin{array}{c}\text { R } \\
\text { Square }\end{array}$ & t & Sig \\
\hline 1. & $\begin{array}{l}\text { Reading } \\
\text { involvement }\end{array}$ & Gender & .033 & 3.301 & .001 \\
2. & $\begin{array}{l}\text { Importance } \\
\text { of reading } \\
\text { Competition } \\
\text { in reading }\end{array}$ & Gender & .021 & 2.568 & .011 \\
3. Gender & .022 & 2.658 & .008 \\
\hline
\end{tabular}

\section{Reading attitude, motivation, and gender}

Interestingly, gender differences were found in all variables (i.e., reading attitude, reading motivation). Girls reported statistically significant higher reading attitude in both academic reading, recreational reading dimensions than boys. This finding is in line with the previous studies claiming that female students reported more positive attitudes compared to male students (Smith, 1990; McKenna et al., 1995; 2012; Kush \& Watkins, 1996; Ghaith, 2003; Swalander \& Taube, 2007; Martinez, Aricak, \& Jewell, 2008; Logan \& Johnston, 2009; McQuillan, 2013; Bussert-Web \& Zhang, 2016). This result might be different if the researchers included academic and recreational 
Murtafi'ah, B., \& Putro, N.H.P.S. (2020). Gender differences in santri's reading attitude and motivation. EduLite: Journal of English Education, Literature, and Culture, 5 (2), 251-262. DOI: http://dx.doi.org/10.30659/e.5.2.251-262

reading in digital settings as boys tend to have more positive attitude towards reading in digital prints (McKenna et al., 2012; Putro \& Lee, 2017). The present study, however, excluded the dimensions of reading attitude in digital setting as the pesantren in which the participants of this study lived have restricted the use of gadget and other digital devices in pondok or madrasah. Therefore, their access to be online was limited.

In the same vein, gender differences were also found in reading motivation dimensions. Girls had statistically significant higher reading motivation in three dimensions, i.e. reading involvement, importance of reading, competition in reading than boys. This finding is consistent with a study claiming that female students had significantly higher intrinsic reading motivation than male students (Kelley \& Decker, 2009; McGeown et al., 2011) as both reading involvement and importance of reading could be classified as dimensions of intrinsic motivation (Baker \& Wigfield, 1999). Competition in reading, on the other hand, was classified as extrinsic motivation (Baker \& Wigfield, 1999).

It is interesting to find out that the finding in this study, i.e. girls were higher in competition than boys, was contrary to the previous studies from Wigfield and Guthrie (1997) which have demonstrated that girls' mean scores were lower in competition in reading than boys' means. Other studies, however, found that on all scales, or in general, female students reported significantly higher mean scores than boys, indicating that they have higher motivation to read than boys (Baker \& Wigfield, 1999; Marinak \& Gambrell, 2010). The finding of this study, therefore, support this idea as girls reported higher mean scores evenly both in intrinsic and extrinsic motivation.

These findings, therefore, support the statements from the English teachers from all schools that girls tend to be more engaged and thus have higher scores in English lesson than boys. The researchers could also see the difference as students in female classes were found more enthusiastic than those in male classes while completing the questionnaires.

\section{CONCLUSION}

This study has demonstrated, for the first time, the gender differences in reading attitude and reading motivation dimensions among santri in type- $B$ pesantren in Yogyakarta Special Region province. The most obvious finding to emerge from this study is that female students who tend to have more positive attitudes toward reading and higher motivation in reading than male students. Specifically, significant gender differences were found in two dimensions of reading attitude (i.e. academic reading and recreational reading attitude) and three dimensions of reading motivation (i.e. reading involvement, importance of reading, and competition in reading). Therefore, it is suggested for the English teachers in type-B pesantren to encourage their male students especially during the English lesson.

A number of important limitations need to be considered. First, this present study has investigated gender difference on attitude and motivation among santri in terms of reading skill only. This study did not examine these variables in other three language skills of English, i.e. speaking, writing, and 
listening among santri. A similar study investigating whether attitude and motivation of other skills are difference would be interesting.

The current research was limited to the context of santri in Yogyakarta Special Region province only. Future studies might investigate the gender differences between reading attitude and reading motivation, in another province in Indonesia.

The participants of the research were those from pesantren-based senior high school. Meanwhile, based on the researcher's observation, there were other school levels such as elementary school, junior high school, senior high school. Therefore, future studies could conduct the similar research in some pesantren-based junior high schools, or in some pesantren-based elementary schools with young learners as the participants.

Four, this present study was limited to be conducted in type-B pesantren only. While there were other types of pesantren in Indonesia, including those which traditional and modern. Since students living in other pesantren could also be defined as santri, more studies using similar questionnaires can also be conducted in other types of pesantren to explore gender differences in their reading attitude and reading motivation.

Finally, the current research was limited to the investigation of reading in English subject. The results from the participants may also be influenced by their perceptions towards English. Therefore, further study investigating gender differences in reading in Bahasa Indonesia could also be conducted.

\section{REFERENCES}

Baker, L., \& Wigfield, A. (1999). Dimensions of children's motivation for reading and their relations to reading activity and reading achievement. Reading Research Quarterly, 34(4), 452-477.

Bussert-Webb, K., \& Zhang, Z. (2016). Reading attitudes of Texas high school students. Reading Psychology, 424-448. doi:10.1080/02702711.2015.1059396

Bappeda DIY. (2017). Aplikasi Dataku. Retrieved August 14, 2017, from Aplikasi Dataku: http://bappeda.jogjaprov.go.id/dataku/pencarian_data/index

BSNP. (2017). Prosedur Operasional Standar Penyelenggaraan Ujian Nasional Tahun Pelajaran 2016/2017. Jakarta: Kementerian Pendidikan dan Kebudayaan

Conradi, K., Jang, B. G., Bryant, C., Craft, A., \& McKenna, M. C. (2013). Measuring adolescents' attitudes toward reading: A classroom survey. Journal of Adolescent \& Adult Literacy, 56(7), 565-576. doi:10.1002/JAAL.183 
Murtafi'ah, B., \& Putro, N.H.P.S. (2020). Gender differences in santri's reading attitude and motivation. EduLite: Journal of English Education, Literature, and Culture, 5 (2), 251-262. DOI: http://dx.doi.org/10.30659/e.5.2.251-262

Dhofier, Z. (2011). Tradisi pesantren: Studi pandangan hidup Kyai dan visinya mengenai masa depan Indonesia. Jakarta: LP3ES.

Fauzi, M. (2012). Traditional Islam in Javanese society: The roles of kyai and pesantren in preserving Islamic tradition and negotiating modernity. Journal of Indonesian Islam, 6(1), 125-144.

Ghaith, G. M. (2003). Relationship between reading attitudes, achievement, and learners perceptions of Jigsaw II cooperative learning experience. Reading Psychology, 105-121. doi: http://dx.doi.org/10.1080/02702710390197444.

Grabe, W. (2009). Reading in a second language: motivation from theory to practice. Cambridge: Cambridge University Press.

Guthrie, J. T., \& Wigfield, A. (2000). Engagement and motivation in reading . In M. L. Kamil, P. B. Mosenthal, P. D. Pearson, \& R. Barr, Handbook of Reading Research (pp. 403-422). Mahwah, New Jersey: Lawrence Erlbaum Associates.

Harmer, J. (2007). How to teach English. Essex: Pearson Education Limited.

Hidayat, R. (2011). Santri, kyai, and ulama: Framing masculinity within Indonesian religious elites. International Workshop on Masculinities in Asia (pp. 1-14). Singapore: National University of Singapore.

Ilahiyah, A. I., Andina, D. M., Tiven, P. A., \& Cahyono, B. Y. (2019). Indonesian EFL students' reading motivation and writing achievement across gender. Journal of English Education, Literature, and Culture, 4(2), 119-131. doi:http://dx.doi.org/10.30659/e.4.2.119-131

Kelley, M. J., \& Decker, E. O. (2009). The current state of motivation to read among middle school students. Reading Psychology, 466-485. doi:10.1080/02702710902733535

Krashen, S. D. (2004). The power of reading: Insights from the research (2nd ed.). Westport, Connecticut: Libraries Unlimited.

Kush, J. C., \& Watkins, M. W. (2010). Long-term stability of children's attitudes toward reading. Journal of Educational Research, 89(5), 315319. doi:https://doi.org/10.1080/00220671.1996.9941333

Logan, S., \& Johnston, R. (2009). Gender differences in reading ability and attitudes: examining where these differences lie. Journal of Research in Reading, 199-214. doi:10.1111/j.1467-9817.2008.01389.x.

Marinak, B. A., \& Gambrell, L. B. (2010). Reading motivation: Exploring the elementary gender gap. Literacy Research and Instruction, 129-141. doi:10.1080/19388070902803795.

Martinez, R. S., Aricak, O. T., \& Jewell, J. (2008). Influence of reading attitude on reading achievement: A test of the temporal-interaction model. Psychology in the Schools, 1010-1022. doi:10.1002/pits.20348 
McGeown, S., Goodwin, H., Henderson, N., \& Wright, P. (2011). Gender differences in reading motivation: Does sex or gender identity provide a better account? Journal of Research in Reading, 1-9. doi:10.1111/j.14679817.2010.01481.x

McKenna, M. C., Conradi, K., Lawrence, C., Jang, B. G., \& Meyer, J. P. (2012). Reading attitudes of middle school students: Results of a U.S. survey. Reading research quarterly, 47(3), 283-306. doi: 10.1002/RRQ.021.

McKenna, M. C., Kear, D. J., \& Ellsworth, R. A. (1995). Children's attitudes toward reading: A national survey. Reading Research Quarterly, 30(4), 934-956. doi: http://www.jstor.org/stable/748205.

McQuillan, J. (2013). Urban middle and high school students' reading attitudes and beliefs: A large-sample survey. Global Journal of Human Social Science Linguistics \& Education, 13(7), 31-49.

Mori, S. (2002). Redefining motivation to read in a foreign language. Reading in a Foreign Language, 14(2), 91-110.

Muhaimin, A. G. (2006). The Islamic traditions of Cirebon: Ibadat and adat among Javanese muslims. Canberra: ANU E Press.

Nation, I. (2009). Teaching ESL/EFL reading and writing. New York: Routledge.

Petscher, Y. (2010). A meta-analysis of the relationship between student attitudes toward reading and achievement in reading. Journal of Research in Reading, 33(4), 335-355. doi:10.1111/j.14679817.2009.01418.x.

Phuong, H. Y., \& Vo, P. Q. (2019). Students' learning autonomy, involvement and motivation towards their English proficiency. Journal of English Education, Literature, and Culture, 4(1), 1-12. doi:http://dx.doi.org/10.30659/e.4.1.1-12

Putro, N. H., \& Lee, J. (2017). Reading interest in a digital age. Reading Psychology, 778-807. doi:https://doi.org/10.1080/02702711.2017.1341966

Richards, J. C., \& Renandya, W. A. (2002). Methodology in language teaching: An anthology of current practice. Cambridge: Cambridge University Press.

Salikin, H., Bin-Tahir, S. Z., Kusumaningputri, R., \& Yuliandari, D. P. (2017). The Indonesian EFL learners' motivation in reading. Canadian Center of Science and Education, 1O(5), 81-90. doi:10.5539/elt.v10n5p81.

Smith, M. C. (1990). A longitudinal investigation of reading attitude development from childhood to adulthood. The Journal of Educational Research, 83(4), 215-219. doi:10.1080/00220671.1990.10885958.

Swalander, L., \& Taube, K. (2007). Influences of family-based prerequisites, reading attitude, and self-regulation on reading ability. Contemporary Educational Psychology, 206-230. doi:10.1016/j.cedpsych.2006.01.002. 
Murtafi'ah, B., \& Putro, N.H.P.S. (2020). Gender differences in santri's reading attitude and motivation. EduLite: Journal of English Education, Literature, and Culture, 5 (2), 251-262. DOI: http://dx.doi.org/10.30659/e.5.2.251-262

Tullock-Rhody, R., \& Alexander, J. E. (1980). A scale for assessing attitudes toards reading in secondary schools. Journal of Reading, 23(7), 609-614. Retrieved from http://www.jstor.org/stable/40017004.

Unrau, N., \& Schlackman, J. (2006). Motivation and its relationship with reading achievement in an urban middle school. The Journal of Educational Research, 81-101. doi:10.3200/JOER.100.2.81-101.

Wang, J. H.-Y., \& Guthrie, J. T. (2004). Modeling the effects of intrinsic motivation, extrinsic motivation, amount of reading, and past reading achievement on text comprehension between U.S. and Chinese students. Reading Research Quarterly, 39(2), 162-186.

Wigfield, A. \& Guthrie, J.T. (1997). Relations of children's motivation for reading to the amount and breadth of their reading. Journal of Educational Psychology, 89(3), 420-432. 